\title{
The Role and Importance of the Protected Areas' (Emerald Network) Development for Amphibians and Reptiles on the Example of Ukraine in the Context of Various Factors' Influence
}

\author{
Oleksii Marushchak \\ Department of animal monitoring and \\ conservation \\ I. I. Schmalhausen Institute of Zoology \\ NAS of Ukraine \\ Kyiv, Ukraine \\ vse_okei@bigmir.net \\ Volodymyr Tytar \\ Department of animal monitoring and \\ conservation \\ I. I. Schmalhausen Institute of Zoology \\ NAS of Ukraine \\ Kyiv, Ukraine \\ vtytar@gmail.com
}

\author{
Oksana Nekrasova \\ Department of animal monitoring and \\ conservation \\ I. I. Schmalhausen Institute of Zoology \\ NAS of Ukraine \\ Kyiv, Ukraine \\ oneks22@gmail.com \\ Andris Ceirans \\ Department of Ecology \\ Daugavpils University, Institute of Life \\ Sciences and Technologies \\ Daugavpils, Latvia \\ cuskisa@gmail.com
}

\author{
Mihails Pupins \\ Department of Ecology \\ Daugavpils University, Institute of Life \\ Sciences and Technologies \\ Daugavpils, Latvia \\ mihails.pupins@gmail.com
}

\begin{abstract}
Creation and expansion of the Emerald Network (EN) objects is one of the most promising directions of the nature conservation development in Ukraine according to European standards. The aim of EN objects designing is to assess the state of conservation of habitats and flora/fauna species' populations on a pan-European level. It is assumed that the EN should cover at least $60 \%$ of the populations of species and the area of habitats mentioned in Resolutions (4 and 6) of the Berne Convention (1979). Later on, the EN will be integrated into Natura 2000 system. The other countries' experience is of great importance in creating such territories. Since 2004 Latvia have joined this network and included 333 sites (12\% of its territory). In Ukraine, such network is only being developed. Four Ukrainian biogeographical regions are inhabited by 6 amphibian and 5 reptile species for which according to Emerald Biogeographical Seminar ALP (Carpathians) - CON - PAN, 11-13 May 2016, Chisinau, Moldova, the EN in not sufficient, being indicated as IN MOD (moderately developed) in $90 \%$ of cases. A total of 63 suggestions of new EN (1628256,4 ha) objects aiming on herpetofauna conservation among others were designed during 2018-2019 and now are waiting to become candidate sites and later on - a part of Ukrainian EN. Most of these sites represent valuable territories of wild nature in the rivers' floodplains. For Latvia and Ukraine conservation of marginal populations of the following species is important: crested newt Triturus cristatus (Laurenti, 1768), fire-bellied toad Bombina bombina (Linnaeus, 1761), pond turtle Emys orbicularis (Linnaeus, 1758). In the work the importance and the ways in which the EN can act for the above mentioned species' conservation are highlighted, taking into account experience of European Union, future trends in the influence of anthropogenic factors, invasive species and climate change.
\end{abstract}

Keywords-Emerald Network, amphibians, reptiles, conservation.

\section{INTRODUCTION}

Development of Emerald Network (EN), namely designing new sites and expansion and correction of already existing boundaries, is one of the most promising directions of the nature conservation in Ukraine nowadays. The Emerald Network (CM) is a modern network of protected areas of particular importance for the conservation of natural habitats and biodiversity. These areas are called Areas of Special Conservation Interest (ASCI). The legal basis for the creation of the EN is the Berne Convention on the Conservation of European Wildlife and Natural Habitats (1979) in Europe and observer countries, to which Ukraine belongs. 5 January 1999 is a date of the Berne convention's ratification by Ukraine. The territories of the Natura 2000 nature conservation system already include the territories of the Emerald Network after certain country becomes an official member of European Union $[1,2]$. The key reasons for assigning particular territory to the list of perspective "Emerald" objects is the presence of the habitats from Resolution No 4, 1996 and the species of plants and animals from the Resolution No 6, 1998 of the Berne Convention on it. In Ukraine, intensive work on the identification and collection of information on potential objects to be included to the Emerald Network was conducted in 2009-2011. For today the inclusion of new proposed sites to EN is going on and is about to be

Print ISSN 1691-5402

Online ISSN 2256-070X

http://dx.doi.org/10.17770/etr2019vol1.4100 (C) 2019 Oleksii Marushchak, Oksana Nekrasova, Mihails Pupins, Volodymyr Tytar, Andris Ceirans Published by Rezekne Academy of Technologies. 
finished in 2020 [3]. Triturus cristatus, Bombina bombina, and Emys orbicularis are rare and protected herpetofauna species in Ukraine, Latvia and neighbouring countries [4], where the above mentioned species demonstrate decline of the populations' size and frequency of modern findings is getting lower $[5,6,7]$. The main reasons for this include anthropogenic transformation of habitats, impact of climate change, especially in Polissya region (Ukraine) [8], presence of invasive predators [9]. That is why these species require special conservation efforts.

All of them are listed in Resolution No 6 of Berne Convention and have their own codes: E. orbicularis (1220), T. cristatus (1166), B. bombina (1188). For these species according to Emerald Biogeographical Seminar ALP (Carpathians) - CON - PAN, 11-13 May 2016 (Chisinau, Moldova) and Emerald Biogeographic Seminar STE - ALP (Caucasus) - BLS, 6-8 September 2016 - Final Conclusions (Kyiv, Ukraine) the EN in not sufficient in almost all cases. Following this, these species have IN MOD status (EN moderately developed) for Continental, Pannonian and Steppic biogeographical regions which means they require designing of additional Emerald sites to be protected in. For E. orbicularis only $30 \%$ of actual registration points are covered by official $\mathrm{EN}$, for B. bombina this figure is approximately $20 \%$ and only $12 \%$ for $T$. cristatus. What is more, due to rapid decrease of number of modern findings and habitat loss, crested newt is prepared to be included to the next edition of Red Book of Ukraine (2019).

As for 01.03.2019 106 new Emerald sites have been proposed to be included to the EN. Among them there are those proposed by authors of this paper. The main aim of this article is to assess whether new propositions improve the situation with EN sites for the mentioned species' protection and figure out the main risks and drivers that can be avoided according to the type of objects proposed as Emerald sites for protections of herpetofauna among other groups. Also the comparison between Latvian conservation of the species in Natura 2000 objects and Ukrainian Emerald Network taking into account the space of conservation areas will be done.

\section{MATERIALS AND METHODS}

The information of actual state of Emerald network in Ukraine was obtained from official Berne Convention web page through Emerald viewer soft (https://www.coe. int/en/web/bern -convention/emerald-viewer). The data on amphibians and reptiles conservation propositions within newly proposed Emerald sites was obtained from the Ministry of Ecology and Natural resources of Ukraine under the general principles. It should be noted that the authors actively participated in submitting the new Emerald objects' proposals, so original data is also presented in the paper. The info about herpetofauna representatives within the site was collected from the literature and from original authors' data for the past 20 years. The map was created in GIS programs: QGIS v.2.18.28 and DivaGis v.7.5. Statistical analyses was conducted in Statistica v.10. The representativeness of newly designed network is calculated as a percent of the areas designed for herpetofauna conservation from the whole Emerald Network territory in Ukraine and the entire territory of the country. Only the areas of Emerald objects are used in calculations. Habitats of mentioned species themselves occupy much smaller areas within the site, but their assessment has not been conducted yet. These species are confirmed for the site based on registration points and separate findings but it doesn't mean that the whole site territory is inhabited by the species. Nevertheless, site's area is quite reliable figure to assess the percentage of territories where conservation of mentioned 3 species is stipulated. Analytical forecasts related to climate change were carried out using the program BIOCLIM models - DIVA GIS v.7.5 (http:// www.diva-gis.org). Climatic data consisted of 19 bioclimatic variables (http://www.worldclim.org/) [10] with spatial resolution of 2.5 minutes. Personal databases of herpetofauna findings were used: (Ukraine-Nekrasova O., Latvia - Pupins M., Pupina A., Ceirans A.) as well as GBIF (https://www.gbif.org/) of E. orbicularis (1126 points); B. bombina (2235 points); T. cristatus (2017 points) of the Eastern part of the range (from Ukraine to Latvia). For counting points, the SAGA GIS program was used.

\section{RESUlTS AND DISCUSSION}

In 2019 a total of 106 new sites were proposed to be included to Emerald Network of Ukraine. 48 of them are aimed on protection, among other species, of $T$. cristatus, B. bombina and E. orbicularis (Fig. 1).

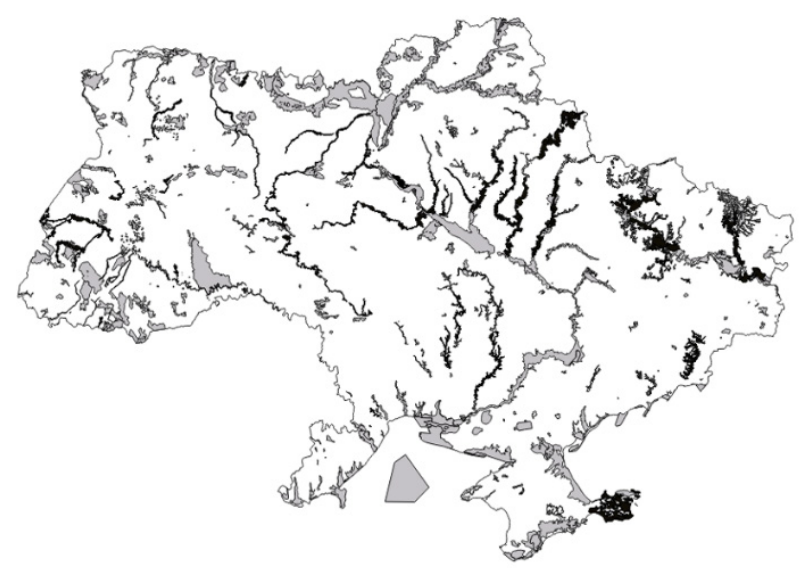

Fig. 1. Emerald Network of Ukraine. EN (2016) is highlighted in grey; newly proposed sites that include protection of T. cristatus, $B$. bombina and $E$. orbicularis are highlighted in black; newly proposed sites where protection of these species is not stipulated are highlighted in white.

E. orbicularis. Official EN of Ukraine provides sites with total area of 3905611,00 ha where protection of pond turtles is stipulated among others. This species is presented in all biogeographical regions: Continental (CON, 2483207,00 ha), Steppic (STE, 1289386 ha), Pannonian (PAN, 5392,00 ha) and Alpine (ALP, 127626,00 ha). Among objects, proposed in 2019 there were no areas from Pannonian and Alpine regions. The total area of newly proposed sites, where pond turtles' protection is stipulated, is 809543,09 ha for Continental region and 355236,08 ha for Steppe region. In total 
the area for the species' conservation is proposed to be increased by $29,82 \%$ (Fig. 2).

B. bombina. Official EN of Ukraine provides sites with total area of 3497774,00 ha where protection of fire bellied toads is stipulated. This species is presented in 3 biogeographical regions: Continental (CON, 2430413,00 ha), Steppe (STE, 1061969,00 ha) and Pannonian (PAN, $5392,00 \mathrm{ha}$ ). Among objects proposed in 2019, there were no areas from the Pannonian and Alpine biogeoregions as well. The total area of newly proposed sites, where fire bellied toads' protection is stipulated, is 719313,12 ha for the Continental region and 295992,19 ha for Steppc biogeoregion. In total the area for the species' conservation is proposed to be increased by $29,03 \%$ (Fig. 2).

T. cristatus. Official EN of Ukraine provides sites with total area of 3478129,00 ha where protection of crested newts is stipulated. This species is presented in Emerald objects of 3 biogeographical regions: Continental (CON, 2685616,00 ha), Steppe (STE, 436052,00 ha) and Alpine (ALP, 356461,00 ha). Among objects proposed in 2019, there were only those situated within the Continental biogeoregion. The total area of newly proposed sites, where crested newts' protection is stipulated, is 3131992,75 ha. In total the area for the species' conservation is proposed to be increased by $12,83 \%$ (Fig. 2).

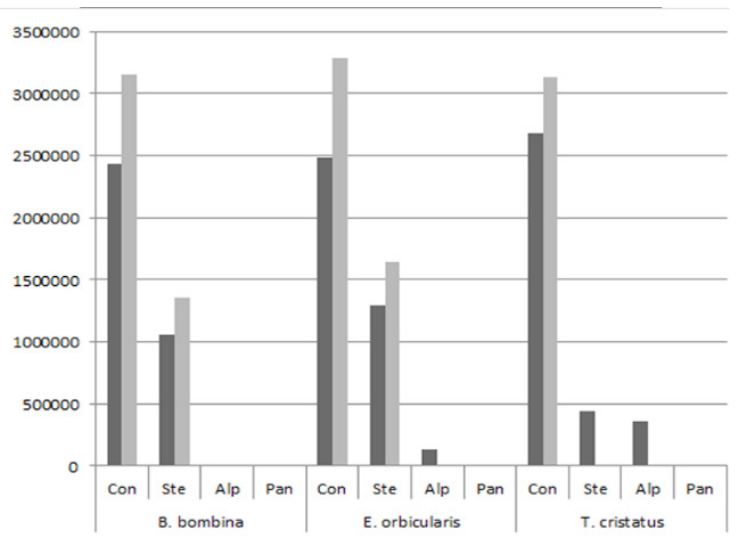

Fig. 2. Areas (ha) of Emerald objects (official network (2016) - dark grey, official network (2016) with proposed sites' areas added - light grey) where E. orbicularis, T. cristatus and B. bombina are mentioned in the list of target protected species of the site.

After the designing of new EN sites the number of registration points covered by the EN has significantly increased for all three species: from $29 \%$ to $42 \%$ for $B$. bombina (Fig. 3), from $15 \%$ to $25 \%$ for T. cristatus (Fig. 4) and from $32 \%$ to $43 \%$ for E. orbicularis (Fig. 5).

In Ukraine $T$. cristatus and $B$. bombina like other rare amphibian species (e.g. natterjack toad, Epidalea calamita (Laurenti, 1768)) continue to suffer from climate change, continuously losing their natural habitats [11]. Invasive fish species are considered to be a serious threat. Eels, carps and other fish prevent breeding success of $B$. bombina completely. Tadpoles usually don't survive and, what is more, adults refrain from spawning in the water that contains fish. In such a case toads will migrate to other localities if possible [12]. Both toads and newts suffer from habitat transformation and fragmentation as well as from invasive species (e. g. Percottus glenii (Dybowski, 1877) [9].

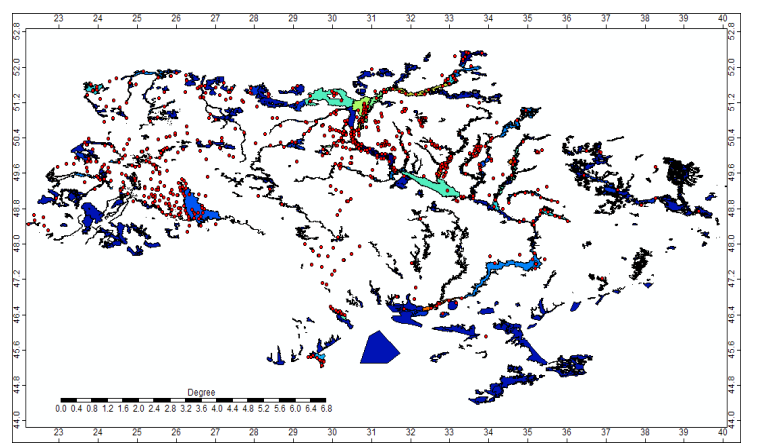

Fig. 3. Coverage of fire bellied toad registration points by extended EN (after adding of newly designed sites).

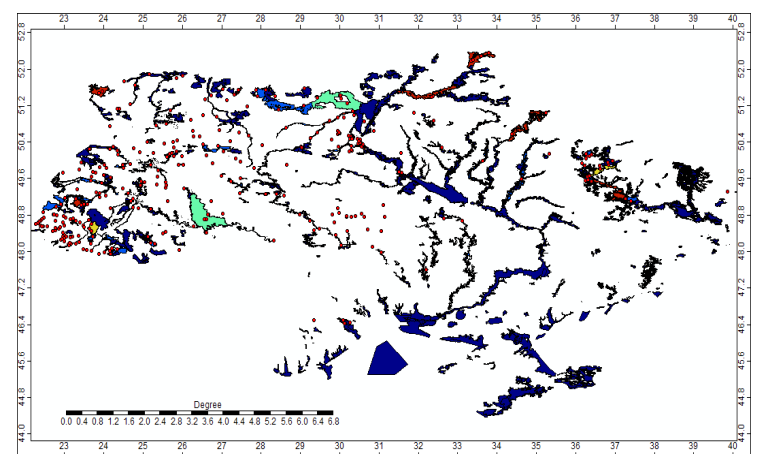

Fig. 4. Coverage of crested newt registration points by extended EN (after adding of newly designed sites).

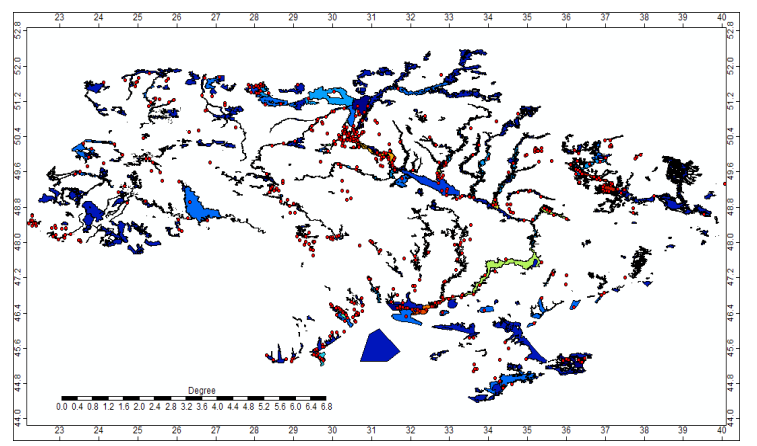

Fig. 5. Coverage of European pond turtle registration points by extended EN (after adding of newly designed sites)

Pond turtles are also becoming prey items for number of invasive predators (golden jackal (Canis aureus Linnaeus, 1758), raccoon dog (Nyctereutes procyonoides Gray, 1834). Numerous cases of turtle clutches' excavation by a raccoon dog indicate a targeted search for it. The eggshell was not found in the faeces, as it remains at the site of the excavated clutch. The situation in Ukraine is quite the same as in Belarus. Currently in the Belarussian Polissya zone approximately $40 \%$ of all turtles' clutches are excavated and eaten by foxes, raccoon dogs, wolves, stray dogs and other predators [4]. These facts are consequences of climate change and anthropogenic activity that allow invasive species to expand their natural areas while bioclimatic zones are slowly moving to the North. This allows to predict that it is highly likely that those countries where only populations' edges of the species were to be found, will become more suitable for them in future. For example, Latvia can be mentioned as a 
country where all 3 species exist $[16,17]$ and are protected at national level within Natura 2000 sites, that occupies $12 \%$ of Latvian territory. Only marginal populations of E. orbicularis, $T$. cristatus and B. bombina exist within the country $[18,19]$ and the percentage of Natura 2000 objects where they are protected is considerably smaller, than in Ukraine, taking into account also the countries size (Fig. 6).

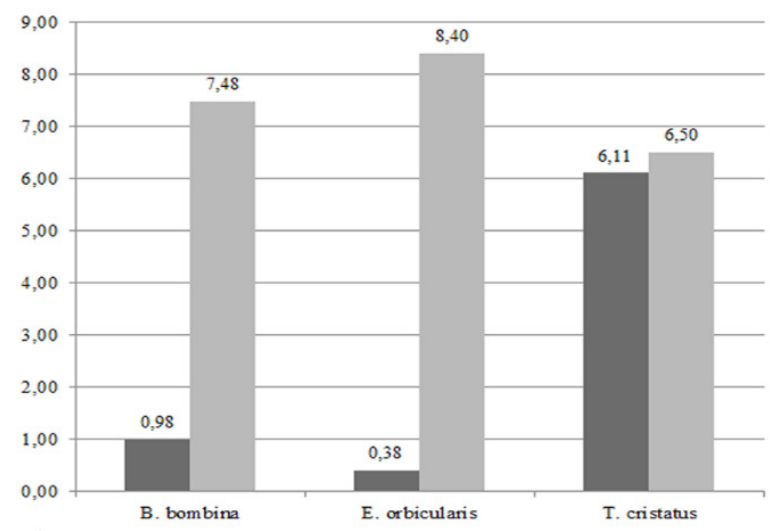

Fig. 6. Percentage of Natura 2000 and Emerald Network areas (from the area of the country) where protection of E. orbicularis, T. cristatus and B. bombina is stipulated: light grey - Ukraine, dark grey - Latvia.

\section{CONClusions}

As a result of GIS modeling, it was revealed that the distribution of amphibians and reptiles depends on such climatic indicators as: Max Temperature of Warmest Month, Max Temperature of Warmest, Mean, Temperature dependence - for E. orbicularis and B. bombina; Temperature Seasonality (standard deviation*100), Temperature Annual Range - for T. cristatus. Modern bioclimatic conditions are favorable for the species on 15 to $18 \%$ of the territory of the Eastern part of the range (from Ukraine to Latvia). In the face of an increase in temperature by $1{ }^{\circ} \mathrm{C}$, it is predicted that the area of this territory will decrease by one and a half times, and the range will shift to the North towards Latvia. Similar trends have been described using other programs [11]. Therefore, the southern populations of amphibians and reptiles will be severely affected. In this regard, the protection of the hydraulic systems (especially southern), such as rivers' valleys, natural marshes and adjacent territories is of great importance. After extending of Emerald Network with newly designed sites, areas, where these species should be protected has increased for all three species. Taking into account the further development of special management plans for each territory and for particular animal groups within, it is thought that more populations of $B$. bombina, T. cristatus and E. orbicularis will be saved in the terms of global climate change and "moving" of biogeographical regions' borders to the North. The creation of the new sites shows a positive trend for further conservation of mentioned species. Currently Ukraine has higher percentage of territories than Latvia, where protection of the 3 species is stipulated. Meanwhile in terms of global climate changes and successful reintroduction practices $[13,14,15]$ in Latvia more space will be required for these species' conservation in future.

\section{ACKNOWLEDGMENTS}

The authors thank anonymous reviewers for constructive comments on the manuscript. We thank the Ministry of Ecology and Natural Resources of Ukraine, International charity ecological organization "Environment. People. Law.", Polish environmental fund "Fundacja Dziedzictwo Przyrodnicze" for their help in collecting of material and work with Standard Data Forms of objects of Emerald Network in Ukraine. The study was conducted in accordance with legislation of Latvia and Ukraine. We thank Daugavpils University for support.

\section{REFERENCES}

[1]. Yu. O. Spinova, O. V. Vasyliuk, "Justification for the inclusion of the Kalmius river valley in the Emerald Network of Ukraine," presented at XI International Conference for young scientists "Biology: from molecule to biosphere", Kharkiv, Ukraine, 2016. (In Ukrainian).

[2]. O. Yu. Marushchak, O. V. Vasyliuk, O. S. Oskyrko, "Perspective object of Emerald Network in Ukraine: Khorol river valley", presented at XIII International Scientific Conference for students and $\mathrm{PhD}$ "Youth and progress of biology," Lviv, Ukraine, 2017. (In Ukrainian).

[3]. K. V. Polyanska, Borysenko K. A., Pawlaczyk P., Vasyliuk O. V., Marushchak O. Yu., Shyriaieva D. V., Kuzemko A. A., Oskyrko O. S., O. D. Nekrasova et al., Involvement of the public and scientists in the designing of the Emerald Network in Ukraine. Kyiv, 2017. (In Ukrainian).

[4]. S. M. Drobenkov, Population ecology of European pond turtle in Belarus. Belaruskaia Nauka, 2012, pp. 1-106. (In Russian).

[5]. N. Smirnov, "On distribution of the Emys orbicularis in IvanoFrankivsk and Chernivtsi regions of Ukraine," presented at III International Conference - Workshop "Research and conservation of european herpetofauna and its environment: Bombina bombina, Emys orbicularis, and Coronella austriaca", Daugavpils, Latvia, 2015.

[6]. A. Strugariu, I. Gherghel, A. Nicoara, M. V. Hutuleac-Volosciuc, V. Moraru, A. Mizerus, "A rapid survey of the herpetological fauna from Vaslui County (Romania) with the first record of the slow-worm (Anguis fragilis) in the region," Herpetologica Romanica, vol. 3, pp. 25-30, Romania 2009.

[7]. O. Nekrasova, V. Tytar, M. Pupins., "Bioclimatic limitations to the geographical distribution of Emys orbicularis (Linnaeus, 1758) (Testudines: Emydidae) in the North of the range," presented at the XV Portuguese-Spanish Herpetology Congress and XIX Spanish Congress of Herpetology "Biology and Conservation of Herps in the Anthropocene", Salamanca, Spain, 2018.

[8]. O. Nekrasova, V. Tytar, V. Kuibida, O. Marushchak, O. Oskyrko, "A GIS-modeling approach to the investigation of rare amphibians and reptiles in Ukraine under climate change," presented at the 4th International Symposium on EuroAsian Biodiversity, Kyiv, Ukraine, 2018.

[9]. A. Pupina, M. Pupins, O. Nekrasova, V. Tytar, I. Kozynenko, O. Marushchak, "Species distribution modelling: Bombina bombina (Linnaeus, 1761) and its important invasive threat Perccottus glenii (Dybowski, 1877) in Latvia under global climate change," Journal of Environmental Research, Engineering and Management, vol. 74, No. 4, pp. 79-86, 2018. DOI 10.5755/j01. erem.74.4.21093V.

[10]. R. J. Hijmans, S. E. Cameron, J. L. Parra, P. G. Jones and A. Jarvis, "Very high resolution interpolated climate surfaces for global land areas," International Journal of Climatology, vol. 25(15), pp. 1965-1978, 2005.

[11]. Tytar, O. Nekrasova, A. Pupina, M. Pupins, O. Oskyrko, "Longterm bioclimatic modelling the distribution of the fire-bellied toad, Bombina bombina (Anura, Bombinatoridae), under the influence of global climate change," Vestnik Zoologii, vol. 52(4), pp. 341-348, 2018.

[12]. K. Fog, H. Drews, F. Bibielriehter, N. Damm and L. Briggs, "Managing Bombina bombina in the Baltic region. Best practice 
guidelines. Amphi consult," Stiftung Naturshutz SchleswigHolsten, Odense, 2011, pp. 1-112.

[13]. M. Pupins, A. Pupina, "Projects on Emys orbicularis (Reptilia: Testudines: Emydidae) in Latvia for thirty years (1984 2014): biological aspects, results and effect on population and ecosystems," Acta Biologica Universitatis Daugavpiliensis, vol.14 (2), pp. 159-175, 2014.

[14]. M. Pupins, A. Pupina, "Project LIFE-HerpetoLatvia: first results on conservation of Emys orbicularis in Latvia," Herpetological Facts, vol. 1, pp. 85-96, 2014.

[15]. A. Pupina, M. Pupins, "Project LIFE-HerpetoLatvia: first results on conservation of Bombina bombina in Latvia," Herpetological Facts, vol. 1, pp. 76-84, 2014.

[16]. A. C. M. Meeske, M. Pupins, K. Rybczynski, "First results on the distribution and condition of the European pond turtle (Emys orbicularis) at the northern edge of its distribution in Lithuania and Latvia", Zeitshrift fur Feldherpetologie, vol. 13 (1), pp. 7199, 2006. (In German).
[17]. S. L. Kuzmin, A. Pupina, M. Pupins, G. Trakimas, "Northern border of the distribution of the red-bellied toad Bombina bombina," Zeitshrift fur Feldherpetologie, vol. 15 (2), pp. 215228, 2008.

[18]. M. Pupins, A. Pupina, "The data on the observations of the European pond turtle (Emys orbicularis L.) at the northern edge of its area in Latvia," Acta Biologica Universitatis Daugavpiliensis, vol. 8 (1), pp. 35-46, 2008.

[19]. A. Pupina, M. Pupins, "The new data on distribution, biotopes and situation of populations of Bombina bombina in the south-east part of Latvia," Acta Biologica Universitatis Daugavpiliensis, vol. 8 (1), pp. 67-73, 2008. 